\title{
Gene Expression Levels of Selected Factors in Monocytic Leukemia Cell Line THP-1 Upon Treatment with $n$-butanol Extract of Atractylis flava Desf against Cancer
}

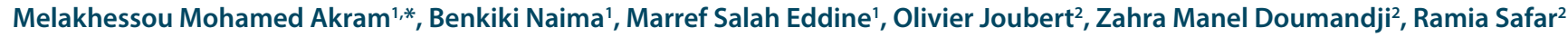 \\ 'Laboratoire de Biotechnologie des Molécules Bioactives et de la Physiopathologie Cellulaire. Université de Batna-2, 05000, ALGERIE. \\ 2Faculté de Pharmacie, EA 3452 CITHÉFOR, Université de Lorraine, 5 rue Albert Lebrun, 54000 Nancy, FRANCE.
}

\begin{abstract}
Objective: The aim of the present study was to screen the anticancer activity of Atractylis flava Desf in butanolic extract (AFBE). In addition, we attempted to investigate the gene expression levels of seven relevant genes involved in the pathways leading to toxicity: oxidative stress (NCF1, OPA1, SDHA), inflammation (TNF $\alpha$ ), apoptotic balance (PDCD4, BCL2, CASP8) and the measurement of caspase-3 activity on the acute monocytic leukemia cell line THP-1. Material and Methods: The cell viability was assessed using Trypan blue exclusion, alamarBlue $\AA$ and WST-1 assays. The gene expression levels were tested by RT-qPCR. Activity of caspase-3 activity was performed using the EnzChek $\circledast$ Caspase-3 Assay kit to confirm the induction of apoptosis on tumor cells. Results: We observed significant growth inhibitory activity of the AFBE extract on the acute monocytic leukemia cell line THP-1. Moreover, the gene expression analysis showed that the plant extract caused statistically significant downregulation of selected genes compared to the untreated cells. Caspase- 3 activity in the treated cells was
\end{abstract}

significantly elevated. Conclusion: The presents study states that the butanolic extract of Atractylis flava Desf showed a significant cytotoxic effect against THP-1 cells. Our results suggest that the AFBE may be beneficial for the treatment and prevention of cancer.

Key words: Atractylis flava Desf, Gene expression, RT-qPCR, Apoptosis, THP-1.

\section{Correspondence}

Dr. Melakhessou Mohamed Akram, Laboratoire de Biotechnologie des Molécules Bioactives et de la Physiopathologie Cellulaire. Université de Batna-2, 05000, ALGERIE.

Phone: +213770202117

Email: Akram_med@hotmail.fr

DOI: 10.5530/jyp.2019.11.8

\section{INTRODUCTION}

Cancer is a large group of diseases, all of which have one thing in common i.e. cells growing out of control or fundamentally a disease of tissue growth regulation failure. In order for a normal cell to transform into a cancer cell, the genes which regulate cell growth and differentiation must be altered. ${ }^{1}$ Anticancer drugs can destroy tumors and arrest cancer progress but cancer treatment may damage healthy cells and tissues. ${ }^{2}$ Cancer may be successfully treated with chemotherapy. However, chemotherapeutic agents are highly toxic to a wide range of normal body cells and thus are associated with diverse side effects. In addition, multiple drug resistance is a major determinant of chemotherapy failure. Therefore, natural products including, traditional medicinal plants, have emerged as a tempting more tolerated alternative with minimum side effects. $^{3}$

The species Atractylis flava Desf. belongs to the genus Atractylis L. of the family Asteraceae(Compositae) is a kind of endemic plant of North Africa. ${ }^{4-5}$ A small number of Atractylis spices have been studied for their phytochemical composition. Therefore, the knowledge about phytochemical investigations of Atractylis plants is very scanty, amongst these plants; A. flava, A. macroceohala and A. gummifera from which flavonoids, polysaccharide, triterpenes and diterpenes were identified. ${ }^{6,7}$ Moreover, Atractylis species are used as general remedies in traditional medicine for treatment of various diseases such as inflammation, ulcer, tumor and circulatory disorders, hepatitis, when Atractylis flava Desf is particularly known in traditional North African medicine for its diuretic effects. ${ }^{8-10}$
The objective of this study was to examine the cytotoxic effects of Atractylis flava Desf. Our investigation was based on the changes in the gene expression levels of selected factors such as B-cell CLL/ lymphoma 2 (BCL2), caspase 8 (CASP8), neutrophil cytosolic factor 1 (NCF1), mitochondrial dynamin like GTPase (OPA1), programmed cell death 4 (PDCD4), Succinate dehydrogenase complex subunit A (SDHA), tumor necrosis factor-alpha (TNFa) and the measurement of caspase- 3 activity on the acute monocytic leukemia cell line THP-1treated with AFBE.

\section{MATERIALS AND METHODS}

\section{Plant Material}

The whole plant Atractylis flava Desf was collected from Biskra Algeria in May 2015. The plant material was identified by Prof. Bachir Oudjehih of the Agronomic Institute of Banta 1 University, Algeria. A voucher specimen number (660/LCCE) was deposited in the herbarium of the mentioned department.

\section{Extraction}

The collected whole plant Atractylis flava was air-dried and powdered. $500 \mathrm{~g}$ powder was macerated with $\mathrm{MeOH}-\mathrm{H}_{2} \mathrm{O}(80: 20)$. After filtration, the filtrate was concentrated under vacuum at room temperature the hydro alcoholic extract was submitted to liquid-liquid fractioning using solvents with increasing polarities (petroleum ether, dichloromethane, ethyl acetate and $n$-butanol). 


\section{Cell culture}

The human monocytic THP-1 (ATCC ${ }^{\circledR}$, TIB-202 $2^{\text {is }}$, Manassas, VA, USA) non-adherent monocyte cell line was grown in RPMI 1640 medium. Supplemented with $2 \mathrm{mM}$ of L-glutamine, $10 \%$ of heat-inactivated fetal bovine serum, $100 \mathrm{U} / \mathrm{mL}$ of penicillin, $100 \mu \mathrm{g} / \mathrm{mL}$ of streptomycin and $0.25 \mu \mathrm{g} / \mathrm{mL}$ of amphotericin B were added. Cells were grown at $37^{\circ} \mathrm{C}$ under $5 \% \mathrm{CO}_{2}$ atmosphere and split every 3 days.

\section{Evaluation of cell viability}

The THP-1 monocytic cell line was seeded in 96 well plates with $5 \times 10^{3}$ cells per well. After overnight incubation, plates were centrifuged $(300 \times \mathrm{g}$, $20 \mathrm{~min}$ ) and the medium was removed by aspiration. Fresh medium was added and cells were incubated for $24 \mathrm{~h}$ with 12.5, 50, 100, 200, 400 and $800 \mu \mathrm{g} / \mathrm{mL}$ of $A F B E$. Six wells were used per culture condition and experiments were repeated thrice. After $24 \mathrm{~h}$, the cell viability was checked using alamar Blue ${ }^{\varpi}$ and WST-1 assays, performed according to manufacturer's protocols. The fluorescence and absorbance were measured at 570/585 nm 585 and $415 \mathrm{~nm}$, respectively. Numbers of dead and alive cells were estimated by microscopy (objective $\times 40$ ) in Glasstic ${ }^{\circ}$ Slides 10 (Kova International, Garden Grove, CA) using trypan blue.

\section{Gene expression analysis by real time PCR (qRT-PCR)}

Expression of B-cell CLL/ lymphoma 2 (BCL2), caspase 8 (CASP8), neutrophil cytosolic factor 1 (NCF1), mitochondrial dynamin like GTPase (OPA1), programmed cell death 4 (PDCD4), Succinate dehydrogenase complex subunit A (SDHA) and tumor necrosis factor-alpha (TNFa) genes by leukemic cells (THP-1) was assessed. Total RNA was extracted from $1.5 \times 10^{6}$ THP-1 cells unexposed or exposed for $4 \mathrm{~h}$ to 25 and $100 \mu \mathrm{g} / \mathrm{mL}$ of $A F B E$ by TRIzol ${ }^{\circledR}$ Reagent (Invitrogen, La Jolla, CA). RNA purity and degradation were checked by spectrophotometry using BioSpecnano (Shimadzu Corporation, Kyoto, Japan) and capillary electrophoresis using RNA $6000 \mathrm{Nano}^{\circ}$ kit and the Bioanalyzer 2100 (Agilent Technologies, Santa Clara, CA). The complementary DNA (cDNA) synthesis was performed with $100 \mathrm{ng}$ of total RNA using the iScript $^{\mathrm{m}}$ cDNA Synthesis Kit (Bio-Rad, Marnes la Coquette, France) following the manufacturer's protocol. Gene expressions were determined by qRT-PCR with the $\mathrm{iQ}^{\text {mx }}$ SYBR Green ${ }^{\star}$ Supermix (Bio-Rad) in a Stratagene Mx3000p system (Agilent Technologies). Briefly, $4 \mu \mathrm{L}$ of each cDNA sample was amplified in a PCR reaction (final volume of $20 \mu \mathrm{L}$ ) containing $10 \mu \mathrm{L}$ of PCR reagent and $300 \mathrm{nM}$ of each two primers (Table 1). For all the samples, the following conditions were used: an initial heat-denaturing step at $95^{\circ} \mathrm{C}$ for 5 min followed by 40 cycles of $95^{\circ} \mathrm{C}$ for $15 \mathrm{~s}$, annealing at $60^{\circ} \mathrm{C}$ for $40 \mathrm{~s}$ and elongation and signal acquisition at $72^{\circ} \mathrm{C}$ for $40 \mathrm{~s}$. To confirm the amplification of specific transcripts, melting curve profiles were produced at the end of each reaction and if two or more peaks were presents, the corresponding results were excluded. Water was used for negative controls for each PCR run. For each gene, amplifications were performed from three independently prepared samples. Gene expression levels were normalized by comparison to $\beta$-actin (ACTB) housekeeping gene, used as references for THP-1. Fold changes (FC) of gene expression were calculated by $2^{-\Delta \Delta \mathrm{Ct}}$ method. ${ }^{11}$

\section{Caspase- 3 activity determinations}

Caspase-3 activity of AFBE in cell lysates was measured using the EnzChek ${ }^{\oplus}$ Caspase-3 Assay kit and processed for caspase-3 enzyme activity assay following the manufacturer's protocol. In brief, the cells were washed with PBS and lysed using cold cell lysis buffer. Next, the cell suspension was centrifuged and the supernatant was collected and incubated with $50 \mu \mathrm{L}$ of $2 \mathrm{X}$ reaction buffer along with $5 \mu \mathrm{L}$ of $1 \mathrm{mM}$ caspase- 3 substrate (DEVD-pNA, $50 \mu \mathrm{M}$ final concentration) at $37^{\circ} \mathrm{C}$ for

\begin{tabular}{|c|c|c|}
\hline $\begin{array}{l}\text { Functional } \\
\text { class }\end{array}$ & Gene & Sequence \\
\hline \multirow{3}{*}{ Apoptosis } & $\begin{array}{l}\text { ACTB } \\
\text { (internal } \\
\text { control) }\end{array}$ & $\begin{array}{c}\text { F:5'-TTGGCAATGAGCGGTTCC-3' } \\
\text { R:5’-GTACTTGCGCTCAGGAGGAG-3 }\end{array}$ \\
\hline & PDCD4 & $\begin{array}{l}\text { F: 5'-'AGACCAAATGAAAAGAGGTTATGAG-3' } \\
\text { R: 5'-GCCCCTTGAAGGACAAAGAT-3' }\end{array}$ \\
\hline & BCL2 & $\begin{array}{l}\text { F: 5'-GAGGATTGTGGCCTTCTTTG-3' } \\
\text { R: 5'-GCATCCCAGCCTCCGTTAT-3' }\end{array}$ \\
\hline \multirow{3}{*}{$\begin{array}{l}\text { Oxidative } \\
\text { stress }\end{array}$} & CASP8 & $\begin{array}{l}\text { F: 5'-GAAAGGGTGGAGCGGATTAT-3' } \\
\text { R: 5'-GCTTCCTTTGCGGAATGTAG-3' }\end{array}$ \\
\hline & NCF1 & $\begin{array}{l}\text { F:5'AGAGTACCGCGACAGACATC-3' } \\
\text { R: 5'-TAGTTGGGCTCAGGGTCTTC-3' }\end{array}$ \\
\hline & OPA1 & $\begin{array}{l}\text { F: 5'-CTTCCATGAGGGTCCATTTG-3' } \\
\text { R: 5'-CCGTTAGCCCTGAGACCATA-3' }\end{array}$ \\
\hline & SDHA & $\begin{array}{l}\text { F: 5'-GCCAGGACCTAGAGTTTGTTC-3' } \\
\text { R: 5'-GCCTTGACTGTTAATGAGAATGC-3' }\end{array}$ \\
\hline Inflammation & $\mathrm{TNF} \alpha$ & $\begin{array}{l}\text { F: 5'-TAGCCCATGTTGTAGCAAACC-3' } \\
\text { R: 5'-GATGGCAGAGAGGAGGTTGA-3' }\end{array}$ \\
\hline
\end{tabular}

$30 \mathrm{~min}$. The caspase- 3 activity of $A F B E$ was then measured in a microplate reader at $342 / 441 \mathrm{~nm}$.

\section{Statistical analysis}

Data are presented as the means \pm standard error (SE) of three independent experiments using GraphPad Prism version 5. The data were compared by one-way ANOVA, followed by Tukey's test in Cell viability assays. Regarding qRT-PCR, FC were calculated by the ratio exposed/ unexposed cells and results were expressed as means \pm SE. Statistical differences between control and exposed cells were determined by ANOVA followed by Dunnett's test. The level of significance was considered when $p<0.05$.

\section{RESULTS}

\section{Effect of the AFBE on THP-1 Cells viability}

After exposure to 25, 50, 100, 200,400 and $800 \mu \mathrm{g} / \mathrm{mL}$ of $A F B E$ for $24 \mathrm{~h}$, a significant decrease of 2 to $4 \%$ of cell viability compared to the control was observed by WST-1 test (Figure 1). The trypan blue test (Figure 2) showed a dose-dependent decrease of $60 \%$ of cell viability after incubation of cells with 100,400 and $800 \mu \mathrm{g} / \mathrm{mL}$ of $A F B E$. In contrast, under the same conditions, a dose-dependent increase in mitochondrial activity of THP-1 human cells up to $250 \%$ at $800 \mu \mathrm{g} / \mathrm{ml}$ was observed with Alamar blue test (Figure 3).

\section{Gene expression analysis}

We have evaluated the effect of AFBE ( 25 and $100 \mu \mathrm{g} / \mathrm{ml}$ ) on the expression of PDCD4, BCL2, CASP8, NCF1, OPA1, SDHA and TNFa. Based on our RT-qPCR data, $A F B E$ significantly decreases the gene expression levels of selected factors after $4 \mathrm{~h}$ of treatment (Figure 4).

\section{Caspase- 3 activity determinations}

The measure of caspase 3 activity in the cells is a direct mean for the determination of caspase dependent apoptosis. Our results showed a significant increase in the caspase 3 activity $(P<0.05$ for $25 \mu \mathrm{g} / \mathrm{mL})$ (Figure 5). 


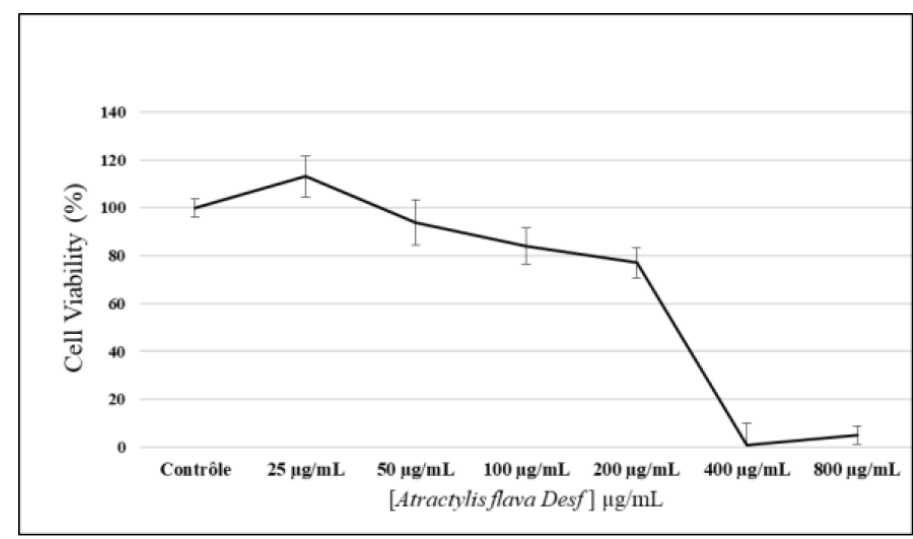

Figure 1: Cytotoxic effect $A F B E$ on cell viability assayed by the WST-1 assay. Cells were incubated with AFBE for $24 \mathrm{~h}(\mathrm{n}=12 \pm \mathrm{SEM})$.

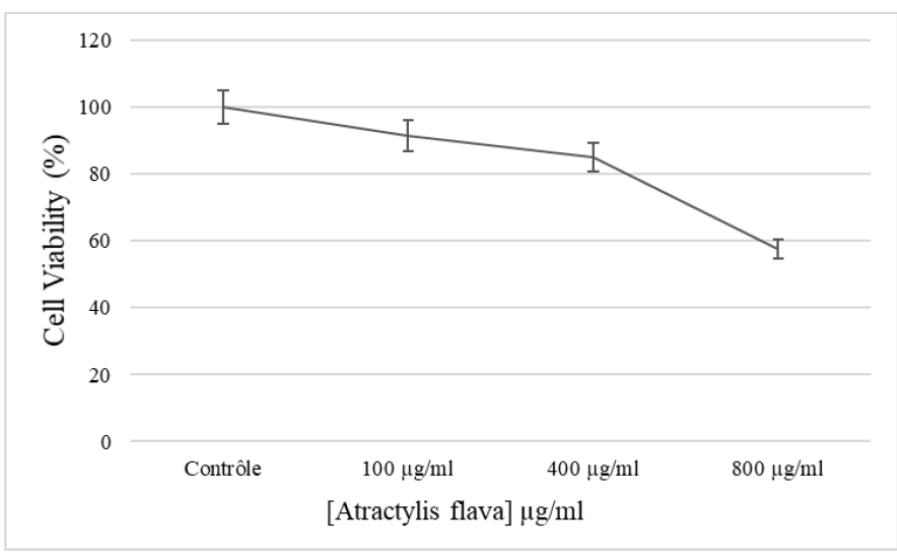

Figure 2: Cytotoxic effect $A F B E$ on cell viability assayed by the Trypan blue assay. Cells were incubated with $A F B E$ for $24 \mathrm{~h}$ ( $\mathrm{n}=12 \pm$ SEM).

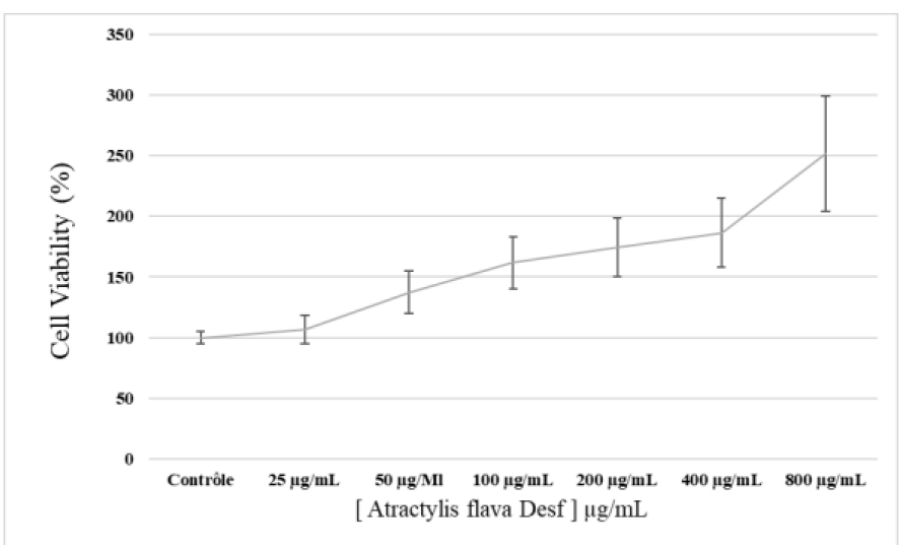

Figure 3: Cytotoxic effect $A F B E$ on cell viability assayed by the Alamar blue assay. Cells were incubated with $A F B E$ for $24 \mathrm{~h}(\mathrm{n}=12 \pm \mathrm{SEM})$.

\section{DISCUSSION}

The study of mitochondrial activity of THP-1 treated with AFBE revealed a fall of THP-1 at $200 \mu \mathrm{g} / \mathrm{ml}$. In addition, the down- regulation of the OPA1 and SDHA genes is said to be the cause, since these observations reflect morphological alterations in mitochondria and deregulation of the respiratory chain. Among the genes responsible of mitochondria

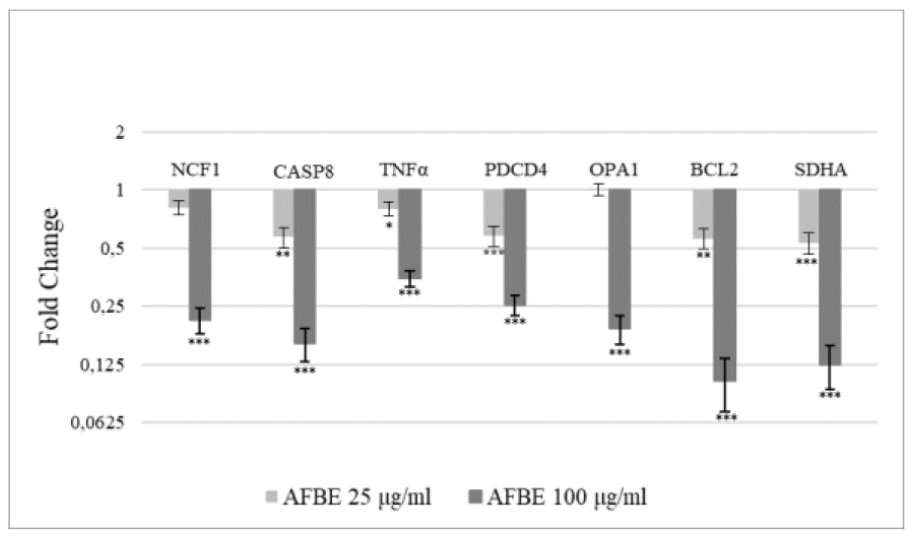

Figure 4: Gene expression changes in response to AFBE exposure of THP-1 human cells. Cells have been exposed to 25 and $100 \mu \mathrm{g} / \mathrm{mL}$ of AFBE for $4 \mathrm{~h}$. Results were presented as fold change as compared to control \pm SEM $(N=4)$ using ANOVA followed by Dunnett's test. $*, p<0.05 * *, p<0.01$ and $* *$, $p<0.001$ indicating a statistical difference versus control.

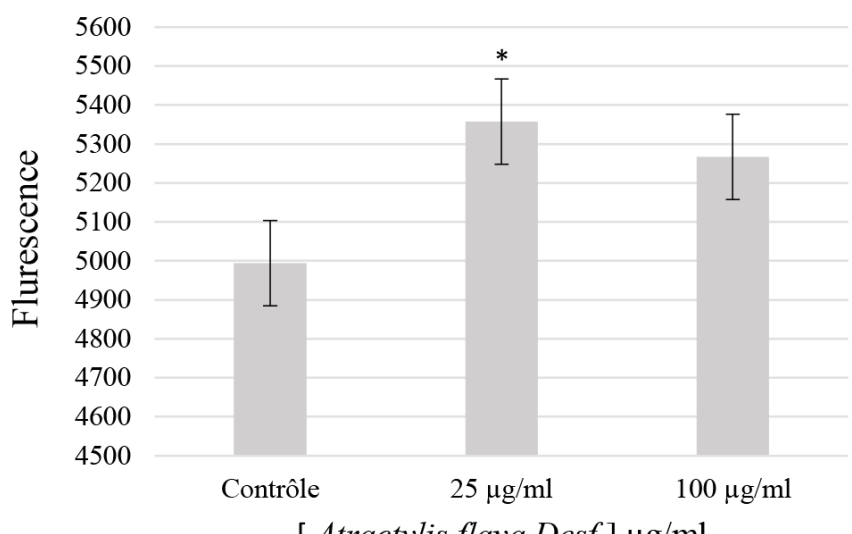

[ Atractylis flava Desf] $\mu \mathrm{g} / \mathrm{ml}$

Figure 5: Detection of caspase-3 activity in macrophage THP-1cell line treated with extract Cells were treated with 25 and $100 \mu \mathrm{g} / \mathrm{ml}$ of plant extract for $4 \mathrm{~h}$. Results are expressed as mean \pm standard deviation using ANOVA followed by Dunnett's test. $*, p<0.05$ indicating a statistical difference versus control.

functions, OPA1 gene plays a major role in the maintenance of the mitochondrial network morphology and dynamics and in regulating cell death signalling pathways. ${ }^{12} \mathrm{~A}$ down regulation of OPA1 has been reported to promote mitochondrial network aggregation and to modify the structure of the mitochondrial inner membrane. ${ }^{13}$ In fact, SDH is an important ROS generation site. ${ }^{14}$ After succinate to fumarate oxidation, which occurs in the SDHA subunit, electrons are transported via the $\mathrm{Fe} / \mathrm{S}$ sites in the SDHB subunit to the coenzyme Q-binding sites formed by the $\mathrm{SDHB} / \mathrm{C} / \mathrm{D}$ proteins, leading to the reduction of ubiquinone and electron flow to the respiratory complex III. ${ }^{15}$ Any interference in this chain of redox reactions results in leakage of electrons and superoxide formation following interaction with molecular oxygen. Indeed, several molecules that target the ubiquinone binding site of SDH eliciting superoxide generation cause apoptosis of cancer cells and are currently under study as potential chemotherapeutics. ${ }^{16}$ Conversely, upstream impairment of succinate oxidation by SDHA subunit can abrogate any elec- 
tron flow to further SDH components, thus inhibiting ROS generation. Further, the TNFa gene, coding for a pro-inflammatory cytokine was down-regulated, this could indicate a reduction in inflammatory processes. Caspase- 3 activation is a crucial component in the apoptotic signaling cascade. To understand how AFBE can be toxic to human monocytic THP-1, we examined the caspase- 3 activity in the AFBE-treated macrophage cells using a caspase-3-specific substrate, DEVD-pNA, which is cleaved to produce a fluorescent product. That caspase-3 activity in the cells treated with AFBE was significantly elevated, which was consistent with the observed effect of this extract on cell viability. This clearly shows that the cytotoxic activity of Atractylis flava Desf can be attributed to apoptosis induction through caspase- 3 activation. Induction of apoptosis in tumour cells is considered a valuable means of treating cancer. ${ }^{17}$ A wide variety of natural substances have been known to induce apoptosis in various tumor cells. It is therefore considered important to filter the apoptotic inducers of plants, either as raw extracts or as isolated components of them. ${ }^{18}$

\section{CONCLUSION}

In conclusion, the findings of the present study demonstrate, for the first time, to the best of our knowledge, that AFBE, causing the down regulation of the gene expressions of all seven factors studied and significantly decreased cell viability and proliferation in the cell lines tested. Indeed, we observe a degradation of mitochondrial activity. This is none other than the consequence of conformational alterations of the mitochondria accompanied by a dysfunction of the Krebs cycle. In addition, AFBE exhibits a down regulation of TNFa this effect may be beneficial for inflammatory diseases. This pathway should be further explored by studying interleukins and interferons.

\section{ACKNOWLEDGEMENT}

The authors wish to express thanks to The General Directorate for Scientific Research and Technological Development (DGRSDT) of the Algerian Minister of Higher Education and Scientific Research for providing a research grant.

\section{CONFLICT OF INTEREST}

The authors declare no conflict of interest.

\section{ABBREVIATIONS}

AFBE: Atractylis flava butanolic extract; BCL2: B-cell CLL/ lymphoma 2 CASP8: Caspase 8; NCF1: Neutrophil Cytosolic Factor 1; OPA1: Mitochondrial dynamin like GTPase; PDCD4: Programmed cell death 4;
SDHA: Succinate dehydrogenase complex subunit A; TNFa: Tumor NeCrosis Factor-alpha.

\section{REFERENCES}

1. Ayesh BM, Abed AA, Faris DM. In vitro inhibition of human leukemia THP-1 cells by Origanum syriacum L. and Thymus vulgaris L. extracts. BMC Research Notes. 2014;7(1):612.

2. Butterfield DA, Abdul HM, Opii W, Newman S, Joshi G, Ansari MA. Review: Pin 1 in Alzheimer s disease. Journal of Neuro Chemistry. 2006;98(6):1697-706.

3. Cecchini G. Function and structure of complex II of the respiratory chain. Annu Rev Biochem. 2003;72(1):77-109.

4. Kluckova K, Bezawork-Geleta A, Rohlena J, Dong L, Neuzil J. Mitochondrial complex II, a novel target for anti-cancer agents. Biochim Biophys Acta. 2013;1827(5):552-64.

5. Chabani S, Haba H, Lavaud C, Benkhaled M, Harakat D. Flavonoid glycosides and triterpenoids from Atractylis flava. Phytochem Lett. 2013;6(1):9-13.

6. Chabani S, Lavaud C, Benkhaled M, Harakat D, Long C, Haba H. Three new oleanane-type triterpene saponins from Atractylis flava. Phytochem Lett. 2016;15:88-93.

7. Chen HW, Su SF, Chien CT, Lin WH, Yu SL, Chou CC, et al. Titanium dioxide nanoparticles induce emphysema-like lung injury in mice. FASEB J. 2006;20(13):2393-5.

8. Daniele C, Dahamna S, Firuzi O, Sekfali N, Saso L, Mazzanti G. Atractylis gummifera L.poisoning: an ethnopharmacological review. J Ethnopharmacol. 2005;97(2):175-81.

9. Dixon SC, Soriano BJ, Lush RM, Borner MM, Figg WD. Apoptosis: its role in the development of malignancies and its potential as a novel therapeutic target. Ann Pharmacother. 1997;31(1):76-82.

10. Drose S. Differential effects of complex II on mitochondrial ROS production and their relation to cardioprotective pre- and postconditioning. Biochim Biophys Acta. 2013;1827(5):578-87.

11. El Rhaffari L, Zaid A. Pratique de la phytothérapie dans le sud-est du Maroc (Tafilalet). Un savoir empirique pour une pharmacopée rénoveé. Dans J. Fleurentin (éd.), Des sources du savoir aux médicaments du futur, IRD editions, Paris. 2000;293-318.

12. Kamei S, Chen-Kuo-Chang M, Cazevieille C, Lenaers G, Olichon A, Belenguer $P$, et al. Expression of the Opa1 mitochondrial protein in retinal ganglion cells: its downregulation causes aggregation of the mitochondrial network. Invest Ophthalmol Vis Sci. 2005;46(11):4288-94.

13. Kephalas T, Alikaridis F, Pantelia K, Papadakis D. Production of carboxyatractyloside and atractyloside by cell suspension cultures of Atractylis gummifera. Phytochemistry. 1999;51(1):53-4.

14. Bingya L, Lewis E, Lucas Z, Yu B, Xu N, Joshua LD. Protecting the normal in order to better kill the cancer. Cancer Med. 2015;4 (9):1394-403.

15. Ozenda P, Flore DS. $2^{\text {nd }}$ ed. C.N.R.S, Paris. 1983;56(67):416-63.

16. Quezel P, Santa $S$. Nouvelle flore de l'Algérie et des régions désertiques méridionales. CNRS, Paris, France. 1963.

17. Taraphdar AK, Roy M, Bhattacharya RK. Natural products as inducers of apoptosis: implication for cancer therapy and prevention. Curr Sci. 2001;80:1387-96.

18. Yong-guang B, Ding-long Y, Min-xia H, Yu-min LI. Study on Ultrasonic-assisted Extraction of Polysaccharide of Atractylis Macroceohala Koidz of Experiment1. Energy Procedia. 2012;17:1778-85.

Article History: Submission Date : 04-07-2018; Revised Date : 15-08-2018; Acceptance Date : 25-10-2018.

Cite this article: Akram MM, Naima B, Eddine MS, Joubert O, Doumandji ZM, Safar R. Gene Expression Levels of Selected Factors in Monocytic

Leukemia Cell Line THP-1 Upon Treatment with n-butanol Extract of Atractylis flava Desf against Cancer J Young Pharm. 2019;11(1):36-9. 